\title{
Determination of the Level of Selected Heavy Metals from Khat Leaves (Cata Edulis Forsk) Grown in Gidolle, Konso and Koyira, Southern Ethiopia
}

\author{
Sleshi Fentie Tadesse ${ }^{1}$, Worku Lakew Kebede ${ }^{2}$ \\ ${ }^{1}$ Analytical Chemistry Stream, Department of Chemistry, College of Natural Science, Arba Minch University, Arba Minch, Ethiopia \\ ${ }^{2}$ Physical Chemistry Stream, Department of Chemistry, College of Natural Science, Arba Minch University, Arba Minch, Ethiopia
}

\section{Email address:}

slefent058@gmail.com (S. F. Tadesse),workulakew@ymail.com (W. L. Kebede)

\section{To cite this article:}

Sleshi Fentie Tadesse, Worku Lakew Kebede. Determination of the Level of Selected Heavy Metals from Khat Leaves (Cata Edulis Forsk) Grown in Gidolle Konso and Koyira, Southern Ethiopia. Science Journal of Analytical Chemistry. Vol. 3, No. 6, 2015 , pp. 115-121. doi: $10.11648 /$ j.sjac.20150306.16

\begin{abstract}
Khat (Catha edulis forsk), a plant used as a stimulant is grown in certain areas of East Africa and the Arab Peninsula. In Ethiopia, it is cultivated in most parts of the country and distributed to local consumers and in other countries. Many farmers have adopted modern farming methods such as application of fertilizers, pesticides and irrigation for Khat cultivation. These agricultural practices are known to increase the concentration of heavy metals in soil and khat. Some of these heavy metals such as $\mathrm{Pb}$ and $\mathrm{Cd}$ are toxic even at low concentrations while $\mathrm{Zn}, \mathrm{Cu}, \mathrm{Fe}$ and $\mathrm{Cr}$ though essential in the body, are toxic at high levels. Therefore this study determined the levels of $\mathrm{Zn}, \mathrm{Cu}, \mathrm{Fe}, \mathrm{Pb}, \mathrm{Cd}$ and $\mathrm{Cr}$ in khat where the plant is grown. Three different types of Khat samples grown in Gidolle, Konso and Koyira were collected from the growing area.0.5 $\mathrm{g}$ of oven dried Khat samples were digested by wet digestion using $3 \mathrm{~mL}$ of $\mathrm{HNO}_{3}, 1 \mathrm{~mL}$ of $\mathrm{HClO}_{4}$ and $1 \mathrm{~mL}$ of $\mathrm{H}_{2} \mathrm{O}_{2}$ by setting the temperature first to $60^{\circ} \mathrm{C}$ for $30 \mathrm{~min}$ and then increased to $210^{\circ} \mathrm{C}$ for the next $2 \mathrm{~h}$ and 30 min.. The digests were analyzed for selected heavy metals using flame atomic absorption spectrophotometer. The following concentration ranges in dry weight $(\mu \mathrm{g} / \mathrm{g})$ were obtained in khat: Fe (180-222), $\mathrm{Zn}$ (25.23-33.69), $\mathrm{Cu}$ (12.64-15.74), $\mathrm{Cr}$ (4.01-4.53). The toxic metals (Pb and Cd) were not detected in all the samples analyzed. The ANOVA results suggested that there was significant difference $(p<0.05)$ in the levels of heavy metals between khat varieties. Levels of studied heavy metals in khat were within in the range of maximum recommended RDA value. Based on this study the analyzed khat are free from toxic heavy metals and do not pose a health risk rather it is a source of essential nutrients for the chewers.
\end{abstract}

Keywords: Khat, Catha Edulis Forsk, Heavy Metals, Konso, Gidolle, Koyira, FAAS

\section{Introduction}

Khat (Catha edulis Forsk) is an evergreen perennial shrub plant that belongs to the Celastraceae family. It is widely cultivated in East Africa and Arabian Peninsula more specifically in Yemen [1]. It is a mild stimulant herb that contains the alkaloids cathine and cathinone which have amphetamine like properties and produces a variety of pleasurable effects. The plant is known with different vernacular names such as chat in Ethiopia, qat in Yemen, qaad/jaad in Somalia andmiraa/ veve in Kenya [1, 2, 3].

Its young leaves andstem tips contains higher proportions of cathinone, which is responsible formuch of the stimulant effect of khat $[2,4]$. Khat chewing is highly prevalent in East
African and some Middle Eastern countries. In Africa it is well distributed in Ethiopia, Eriteria, Somalia, Kenya, Zambia, Rwanda and South Africa. Outside Africa, it is planted in Arabian Peninsula, Afghanistan, Yemen and Sir Lanka $[5,6]$. Fresh leaves from khat trees are chewed daily by over 20 million people on the Arabian Peninsula and East Africa $[3,7,8]$.

Its use is both a social and a culture-based activity and it is said to enhance social interaction. On average, almost $70 \%$ of households in Yemen and 50\% in Djibouti use khat [9], and more than $30 \%$ of Ethiopians have been reported to use khat [10]. It is a major source of income besides being chewed for its stimulating effect. The varieties and chemical profile of khat leaves depend upon the environment, climate condition and geographical area of cultivation [1]. They differ in color, 
size and height of the leaves and size and height of the plant as a whole and the most favored part of the plant is its leaves, particularly the young shoots near the top [11].

In Ethiopia, khat is grown in most parts of the country, there is an ever-growing demand both for domestic consumption and for the export market. Most of the exported khat is grown in the eastern and southern part of the country and mainly exported to the neighboring and the Middle East countries, and in recent years, the market for khat has grown to Europe and America [6]. Its use is widespread and cultivated in most parts of Ethiopia, where its use is socially sanctioned and even prestigious [10]. To date, it is a common practice among many individuals particularly in the eastern, southern, and some parts of northern parts of the country.

In Ethiopia, the plant is marked under different names where some of them are commonly exported to the neighboring countries while the remaining is chewed by the local people around. Most names of khat are derived from the name of the place where the plant is growing. Example, Bahir Dar khat is cultivated in Bahir Dar, Konso khat is cultivated in konso, and Gidolle is cultivated in Gidolle. They differ in color, size, and height of the leaves and size and height of the plant as a whole.

Khat requires well-drained field with $\mathrm{pH}$ range of 6.0 to 8.2. The optimal altitude and annual rainfall for its growth range from 1,500 to $2,100 \mathrm{~m}$ and 1,000 to $1,500 \mathrm{~mm}$, respectively $[1,6]$. It is subject to a wide range of insect pests, diseases, weeds, and animals that damage its leaves, newly growing shoots, stems, and roots. As a result, uses of synthetic insecticides are becoming increasingly common. In addition to pesticides application, uses of fertilizers are the common practice among khat cultivators [6].

The soil on which khat grows is a good source of essential elements for human beings; However the presence of nonessential elements such as lead and cadmium in the soil leads to their uptake by khat. A number of minerals essential to human nutrition are accumulated in different parts of plants as it accumulates minerals essential for growth from the environment and can also accumulate metals such as $\mathrm{Cd}$ and Co which are no known direct benefit to the plant $[11,12$, 13].It has been reported that traces of $\mathrm{Cd}$ and $\mathrm{Pb}$ can be detected in all plants and foodstuffs. These metals end up in the soil from different sources which include agricultural practices such as application of phosphatic fertilizers, pesticides and derived composts [3]. Heavy metals in fertilizer amended soils were higher when compared to those in natural soils due to soils retaining heavy metals sourced from the applied fertilizers [14].

The input of heavy metals to soil from various sources may prove detrimental to plant through its uptake to toxic limit, thereby facilitating its entry into the food chain. These metals have the capacity to affect harmfully the activity of a living organism, its growth, health, life span and reproduction performance $[3,15]$. They are extremely persistent in the environment, non-biodegradable and thus readily accumulate to toxic levels [16] and therefore pose a significant health risk to human particularly in elevated concentrations.

Absorption and accumulation of heavy metals in plants are influenced by many factors including: concentration of heavy metals in soils, consumption and intensity of atmospheric deposition, including precipitation, phase of plant vegetation $[17,18]$. The nature of soil is considered one of the most important factors that determine heavy metal content of food plants, probably because this is the binding and retention site for the toxicants $[11,17,18]$.

For the last two decades, lots of work has been done with respect to phytochemical studies and pharmacological as well as social effects of khat. However, no adequate works have been made regarding the concentration of essential and nonessential minerals in khat. However, studies done in other countries such as Yemen [19], and inEthiopia [6, 11], have reported presences of heavy metals in khat.

Since Ethiopia is one of the main consumer countries of khat and it is the country where khat plantation is ever increasing. Farmers are accustomed in using chemicals to increase their yield, it is important to investigate the mineral content (both toxic and essential) nutrients of the plant growing in the country. This is very important to evaluate the ability of khat plant in accumulating mineral nutrients and to evaluate their role in disturbing trace element levels in human tissues and body fluids. In addition to these, it is also important to investigate to what extent khat chewing will supplement the daily intake of individual's essential mineral nutrients need. Therefore this study aimed at assessing the levels of selected heavy metals in khat plant growing in different parts of the country so as to address the above issues. Furthermore, the findings of this study will provide adequate information on the distribution of selected heavy metals in the edible portion of the plant material. Therefore, in this study, we have analyzed six element ( $\mathrm{Fe}, \mathrm{Zn}, \mathrm{Pb}, \mathrm{Cd}$, $\mathrm{Cu}$, and $\mathrm{Cr}$ ) contents of edible portion of khat plant growing in the southern regional state of Ethiopia and which have common popularity in local consumption and exported to other parts of region. Hence Konso, Gidolle and Koyira types of khat were selected for this study. Moreover, the findings of this study will provide adequate information on the distribution of trace metals in aforementioned khat types where no works have done before.

\section{Material and Methods}

\subsection{Sample Collection and Preparation}

Study Site Description: khat leaf were collected from different areas of the southern regional state of Ethiopia namely Gidolle, Konso and Koyira. These areas are best known in khat cultivation for local consumption and neighboring regions. The trade name of the khat varieties are expressed by their corresponding growing areas.

Sample Preparation: For each variety of khat sample a total of about50 g bulk khat leaf samples were collected randomly from the selected sampling site and brought to Arba Minch University, College of Natural science, 
Department of Chemistry for further treatment and analysis .The khat leaf samples were air-dried followed by in the oven at $70^{\circ} \mathrm{C}$ for $72 \mathrm{~h}$ (until constant weight) and ground in a blender to homogenize and reduce the size of the particles to pass through a $0.5 \mathrm{~mm}$ sieve and stored in polyethylene bags prior to analysis.

\subsection{Instrumentation and Chemical Reagents}

Instrumentation: A drying oven was used to dry khat samples. Ceramic pestle and mortar were used to ground and homogenize the dried khat sample. All of the khat leaves were weighed on a digital analytical balance .Round bottom flask $(100 \mathrm{~mL})$ fitted with reflux condenser and kjeldhal digestion block were used for the digestion of khat samples .The concentration of $\mathrm{Fe}, \mathrm{Cu}, \mathrm{Zn}, \mathrm{Cr}, \mathrm{Cd}$, and $\mathrm{Pb}$ in khat sample were determined by flame atomic absorption spectrophotometer (Buck Scientific Model 210 VGP, East Norwalk, USA) using an air -acetylene flame.

Reagents and Chemicals: All the reagents used were of analytical grade. Concentrated $\mathrm{HNO}_{3}$ (69-72\%, SPECTROSOL, BDH, UK), $\mathrm{HClO}_{4}(70 \%$, Pine Chem Industries Mumbai, India) and $\mathrm{H}_{2} \mathrm{O}_{2} \quad(30 \%$, Scharlaw, Chemie. S.A) were used for the digestion of khat leaf samples. Stock standard solutions containing $1000 \mathrm{mg} / \mathrm{L}$, in
$2 \% \mathrm{HNO}_{3}$, of the metals ( $\mathrm{Fe}, \mathrm{Zn}, \mathrm{Cu}, \mathrm{Cr}, \mathrm{Cd}$ and $\mathrm{Pb}$ ) were used for the preparation of calibration standards and in the spiking experiments. Deionized water was used throughout the experiment.

\subsection{Methodologies}

Optimization of Digestion Procedure: To select an optimum procedure for digestion, parameters like digestion time, reagent volume, volume ratio of reagents, and digestion temperature were optimized by varying one parameter at a time and keeping the others constant. Parameters giving clear solution at lower temperature, requiring minimum reagent volume and digestion time were selected as an optimum procedure for digestion of khat sample. Finally, for a complete digestion of $0.5 \mathrm{~g}$ the dry sample, $3 \mathrm{~mL} \mathrm{HNO}_{3}(69-$ $72 \%), 1 \mathrm{~mL} \mathrm{HClO}_{4}(70 \%)$ and $1 \mathrm{~mL} \mathrm{H}_{2} \mathrm{O}_{2}(30 \%)$ for a total of $3 \mathrm{~h}$ at variable interval was selected as optimized procedure for the digestion.

Digestion of Khat leaves: Applying the optimized procedure $0.5 \mathrm{~g}$ of dried and ground khat leaves sample was digested using $5 \mathrm{~mL}$ of $3: 1: 1$ mixture of $\mathrm{HNO}_{3}(69-72 \%)$, $\mathrm{HClO}_{4}(70 \%)$ and $\mathrm{H}_{2} \mathrm{O}_{2}(30 \%)$ under reflux. The digests were used to determine concentration of $\mathrm{Fe}, \mathrm{Zn}, \mathrm{Cu}, \mathrm{Cr}, \mathrm{Cd}$ and $\mathrm{Pb}$ by atomic absorption spectroscopy.

Table 1. Optimization of Methods for Digestion of Khat Samples.

\begin{tabular}{|c|c|c|c|c|c|c|}
\hline No. & Samplesize & Reagent added & $\begin{array}{l}{ }^{\mathrm{a}} \text { Intial } \\
\text { Temp. }\end{array}$ & $\begin{array}{l}\text { Final } \\
\text { Temp. }\end{array}$ & $\begin{array}{l}\text { Digestion } \\
\text { time }\end{array}$ & $\begin{array}{l}\text { Nature of Digest After } \\
\text { Filtration }\end{array}$ \\
\hline 1 & $0.5 \mathrm{~g}$ & $2 \mathrm{~mL} \mathrm{HNO}_{3}(69-72 \%), 2 \mathrm{~mL} \mathrm{HClO}_{4}(70 \%), 1 \mathrm{~mL} \mathrm{H}_{2} \mathrm{O}_{2}(30 \%)$ & $60^{\circ} \mathrm{C}$ & $210^{\circ} \mathrm{C}$ & $3 \mathrm{hr}$ & Clear \& Yellowish color \\
\hline 2 & 0.5 & $3 \mathrm{~mL} \mathrm{HNO}_{3}(69-72 \%), 0.5 \mathrm{~mL} \mathrm{H}_{2} \mathrm{SO}_{4}, 1 \mathrm{~mL} \mathrm{HClO}_{4}(70 \%)$ & $60^{\circ} \mathrm{C}$ & $180^{\circ} \mathrm{C}$ & $3 \mathrm{hr}$ & Clear \& Pale Yellow color \\
\hline 3 & 0.5 & $3 \mathrm{~mL} \mathrm{HNO}_{3}(69-72 \%), 0.5 \mathrm{~mL} \mathrm{H}_{2} \mathrm{SO}_{4}, 1 \mathrm{~mL} \mathrm{HClO}_{4}(70 \%)$ & $60^{\circ} \mathrm{C}$ & $180^{\circ} \mathrm{C}$ & $4 \mathrm{hr}$ & Clear \& almost colorless \\
\hline 4 & 0.5 & $2 \mathrm{~mL} \mathrm{HNO}_{3}(69-72 \%), 2 \mathrm{~mL} \mathrm{HClO}_{4}(70 \%), 1 \mathrm{~mL} \mathrm{H}_{2} \mathrm{O}_{2}(30 \%)$ & $60^{\circ} \mathrm{C}$ & $180^{\circ} \mathrm{C}$ & $3 \mathrm{hr}$ & Clear \& Yellowish color \\
\hline 5 & 0.5 & 3 mL HNO3 (69 - 72\%), 1 mL HClO4 (70\%), 1 mL H2 $\mathrm{O}_{2}(30 \%)$ & $60^{\circ} \mathrm{C}$ & $210^{\circ} \mathrm{C}$ & $3 \mathrm{hr}$ & $\begin{array}{l}\text { Clear \& Colorless } \\
\text { Optimum }\end{array}$ \\
\hline
\end{tabular}

Instrument Calibration and Method Detection Limit: To determine method detection limit, replicate analyses for six blank samples were performed, and the pooled standard deviation of the six reagent blanks was calculated. The detection limits were obtained by multiplying the pooled standard deviation of the reagent blank by three. The method detection limits of each metal are given in table 2 . The results clearly show that the calibration curves with good correlation coefficients and lower method detection limits were obtained during the analysis.

Table 2. Method Detection Limit for Khat Leaf $(n=6)$.

\begin{tabular}{lllllll}
\hline Metal & $\mathbf{Z n}$ & $\mathbf{C u}$ & $\mathbf{F e}$ & $\mathbf{C r}$ & $\mathbf{C d}$ & $\mathbf{P b}$ \\
\hline $\begin{array}{l}\text { MDL }\left(\mu \mathrm{g} \mathrm{g}^{-1}\right)^{\mathrm{a}} \\
\text { for khat leaf }\end{array}$ & 0.79 & 1.86 & 9.04 & 1.06 & 0.68 & 6.97 \\
\hline
\end{tabular}

avalues are mean of $3 \times$ standard deviation of six blank determinations each measured three times. MDL: Method Detection Limit

Recovery Test: The efficiency of the optimized procedure was evaluated using recovery experiment that is by adding known concentration of each metal to $0.5 \mathrm{~g}$ of sample. The procedure was as follow: $15 \mu \mathrm{g}$ of $\mathrm{Zn}$ and $10 \mu \mathrm{g}$ of $\mathrm{Cu}$ were spiked at once into $0.5 \mathrm{~g}$ of khat sample, and the remaining metals $(0.8 \mu \mathrm{g}$ of Crand $45 \mu \mathrm{g}$ of $\mathrm{Fe})$ were spiked into another digestion flask containing $0.5 \mathrm{~g}$ of the sample. After digesting the spiked samples following the optimized procedure, each sample was analyzed for their respective spiked metals by atomic absorption spectrophotometer. Recovery test was performed in triplicates. The results of the measurement are presented in table 3. The percentage recoveries of khat sample are between $90 \%$ and $101 \%$, which are within the acceptable range.

Table 3. Recovery Test Results.

\begin{tabular}{|c|c|c|c|c|}
\hline Metal & $\begin{array}{l}\text { Conc. in } \\
\text { sample }\left(\mu g^{-1}\right)^{a}\end{array}$ & $\begin{array}{l}\text { Amount added } \\
\left(\mu \mathrm{g} \mathrm{g}^{-1}\right)\end{array}$ & $\begin{array}{l}\text { Conc. in } \\
\text { spiked sample } \\
\left(\mu \mathrm{g} \mathrm{g}^{-1}\right)^{\mathrm{b}}\end{array}$ & $\begin{array}{l}\text { Percent } \\
\text { recovery }(\%)^{c}\end{array}$ \\
\hline $\mathrm{Zn}$ & 30.5 & 15 & $44.7 \pm 0.24$ & $94.7 \pm 7.6$ \\
\hline $\mathrm{Cu}$ & 16.6 & 10 & $26.7 \pm 0.4$ & $101.0 \pm 1.4$ \\
\hline $\mathrm{Fe}$ & 123.4 & 45 & $166.8 \pm 3$ & $96.4 \pm 8.6$ \\
\hline $\mathrm{Cr}$ & 5.3 & 0.8 & $6.02 \pm 0.03$ & $90.0 \pm 4.2$ \\
\hline
\end{tabular}

a Average value of nine measurements $(\mu \mathrm{g} / \mathrm{g})$, ${ }^{\mathrm{b}}$ Values are mean $\pm \mathrm{SD}$ of triplicate readings of triplicate analyses, ${ }^{c}$ Values are mean $\pm \mathrm{SD}$ of triplicate readings of triplicate

Conversion Factor Determination: To report the result obtained on dry-weight basis in terms of fresh-weight basis, a 
conversion factor was calculated by taking the weight of a known quantity of fresh edible part of the plant before and after drying (at $70^{\circ} \mathrm{C}$ ) to a constant weight. Thus, for all khat types a conversion factor lies between 3.71-3.76 that is 3.71$3.76 \mathrm{~g}$ of fresh (wet) sample yielded $1 \mathrm{~g}$ of dry weight depending on the khat type.

\section{Results and Discussion}

\subsection{Determination of Trace Metals}

Three aliquots of khat samples were taken from each bulk sample, and the data on the different aliquots were combined $(n=9)$ to give one mean value of the particular metal for one particular bulk khat sample. Tables 4 show the mean concentration values of each metal in each sample with its respective relative standard deviation (RSD) in dry-weight basis.

The overall error resulting from sample inhomogeniety and from methods are within the acceptable range $(\mathrm{RSD} \leq 5 \%)$. Since the fresh part of the plant is consumed, the result in terms of the dry-weight basis is converted to freshweight basis so as to correlate intake of the metals with the amount of khat chewed using a conversion factor 3.71-3.76. Table 5 presents the concentration range of each metal in wet-weight basis in the present study.

Table 4. Mean Concentration ( $X \pm S D, n=9, \mu g / g$ dry weight) and Relative Standard Deviation (\% RSD) of trace metals in Khat Samples.

\begin{tabular}{|c|c|c|c|c|c|c|}
\hline \multirow{2}{*}{ Metal } & \multicolumn{6}{|l|}{ Khat Type } \\
\hline & Gidolle & Percent RSD (\%) & Konso & Percent RSD (\%) & Koyira & Percent RSD (\%) \\
\hline $\mathrm{Fe}$ & $180 \pm 2.0$ & 0.9 & $126 \pm 1.0$ & 0.8 & $222 \pm 2.0$ & 0.8 \\
\hline $\mathrm{Zn}$ & $25.23 \pm 0.3$ & 1.2 & $29.9 \pm 0.13$ & 0.43 & $33.69 \pm 0.13$ & 0.39 \\
\hline $\mathrm{Cu}$ & $12.64 \pm 0.14$ & 1.1 & $14.90 \pm 0.12$ & 1.3 & $15.74 \pm 0.09$ & 0.6 \\
\hline $\mathrm{Cr}$ & $4.01 \pm 0.08$ & 1.9 & $6.01 \pm 0.05$ & 0.8 & $4.53 \pm 0.15$ & 3.3 \\
\hline $\mathrm{Cd}$ & $\mathrm{ND}^{\mathrm{a}}$ & & $\mathrm{ND}^{\mathrm{a}}$ & & $\mathrm{ND}^{\mathrm{a}}$ & \\
\hline $\mathrm{Pb}$ & $\mathrm{ND}^{\mathrm{a}}$ & & $\mathrm{ND}^{\mathrm{a}}$ & & $\mathrm{ND}^{\mathrm{a}}$ & \\
\hline
\end{tabular}

${ }^{\text {a }}$ Concentration of the tested heavy metal below the method detection limit

Table 5. Mean Concentration ( $X \pm S D, n=9, \mu g / g$ wet- weight basis) of Trace Metals and Conversion Factor.

\begin{tabular}{|c|c|c|c|c|c|c|c|}
\hline \multirow{2}{*}{ Khat Type } & \multicolumn{6}{|l|}{ Metal } & \multirow{2}{*}{ Conversion Factor } \\
\hline & $\mathbf{F e}$ & $\mathbf{Z n}$ & $\mathbf{C u}$ & $\mathrm{Cr}$ & Cd & $\mathbf{P b}$ & \\
\hline Gidolle & $48.52 \pm 0.42$ & $6.80 \pm 0.13$ & $3.41 \pm 0.10$ & $1.08 \pm 0.02$ & $\mathrm{ND}^{\mathrm{a}}$ & $\mathrm{ND}^{\mathrm{a}}$ & 3.71 \\
\hline Konso & $33.87 \pm 0.18$ & $8.04 \pm 0.05$ & $4,01 \pm 0.05$ & $1.62 \pm 0.03$ & $\mathrm{ND}^{\mathrm{a}}$ & $\mathrm{ND}^{\mathrm{a}}$ & 3.72 \\
\hline Koyira & $59.04 \pm 0.10$ & $8.96 \pm 0.14$ & $4.19 \pm 0.04$ & $1.20 \pm 0.05$ & $\mathrm{ND}^{\mathrm{a}}$ & $\mathrm{ND}^{\mathrm{a}}$ & 3.76 \\
\hline
\end{tabular}

${ }^{\text {a }}$ Concentration of the tested heavy metal below the method detection limit

\subsection{Distribution Pattern of Metals in Khat}

Plants accumulate minerals essential for their growth from the environment and can also accumulate metals such as $\mathrm{Cd}$ and Co, which have no known direct benefit to the plant [20]. Various factors affect the concentration of metals in the plant. These are: nature of chemical and physical property of the soil, climatic condition of the region, and application of fertilizers and pesticides. Increase in population and industrialization results pollution to water, air, and soil which in turn causes in unexpected concentration of trace metals in the plant. Particularly agricultural activities such as use of fertilizers, pesticides, and irrigation with contaminated sewage are the major source of contaminations.

As can be seen from tables 4 , there is a wide variation in concentration of heavy metals within and among the khat varieties. The pattern of concentration of elements in most of khat varieties analyzed were decreased as $\mathrm{Fe}>\mathrm{Zn}>\mathrm{Cu}>\mathrm{Cr}>$, while $\mathrm{Cd}$ and $\mathrm{Pb}$ were below the method detection limit of the analysis.

The concentration of $\mathrm{Fe}$ and $\mathrm{Zn}$, were higher than the entire trace metals in the samples. Since the soil types of khat growing areas of Ethiopia are moderately acidic to slightly basic with the $\mathrm{pH}$ ranges from 5.6 to 7.3 , the plant is expected to have a better accumulation of micronutrients like iron and zinc $[6,11,21] . \mathrm{Cu}$ was also found in a higher concentration. It is an essential macronutrient to the plant, can accumulate ontop soil and is easily bio-available to the plant with decrease in $\mathrm{pH}$ of the soil [22]. Next to $\mathrm{Cu}, \mathrm{Cr}$ was also found in a relatively higher concentration in analyzed khat plant. As reported by [13] $\mathrm{Cr}$ is required by humans, but not by plants. Fortunately for humans, however, plants can acquire these elements through non-specific influx processes using existing transporters localized to their roots. In fact, a wide range of plant's nonessential elements has been measured in plant tissues, with concentrations sometimes reaching dramatic levels if soil availability is high [13].

\subsection{Correlations Among Levels of Metals in Khat of the Three Khat Varieties Analyzed}

The levels of metals in khat varieties are given in table 4 (dry-weight basis). As can be seen from the table, it is impossible to have a common trend for the distribution of all metals in all khat varieties, i.e., some khat varieties accumulate relatively higher concentration of some of the metals while lower concentration for remaining metals relative to the other khat varieties analyzed. This might be 
due to cultivation, different methods of farming and geographical variation. And statistical analysis is performed to see whether the variation of metals in different khat sample is significant or not. One paper published on selected trace metal contents of Yemeni khat using stripping voltammetry, and the result was reported in fresh-weight basis [19]. In the same way Concentration Levels of Essential and Non-essential Metals in Ethiopian Khat was analyzed and reported $[6,11]$. The concentration range of metals in khat samples of the present study in fresh-weight basis (converted using conversion factor) is also shown in table 5. The concentration of $\mathrm{Fe}$ in the present study in analyzed khat type is relatively comparable with the level of Ethiopian khat as determined before $[1,6]$, but it is less than as reported by [24,25]. The mean $\mathrm{Cu}$ and $\mathrm{Zn}$ content of khat in the present analysis ranged from 3.41 to $4.19 \mu \mathrm{g} / \mathrm{g}$ and 6.80 to $8.96 \mu \mathrm{g} / \mathrm{g}$ fresh weights, respectively (table 5). Compared with the literature value, the concentration range of $\mathrm{Zn}$ in the present study (Ethiopian khat) is comparable with the reported value
(Ethiopian and Yemeni khat), and it is within the range (table 6). Though the concentration range of $\mathrm{Cu}$ in the present study is within the reported value, higher concentrationof $\mathrm{Cu}$ within the range of the reported value has been observed in Yemeni khat but comparable with Ethiopian khat. However both $\mathrm{Zn}$ and $\mathrm{Cu}$ have less concentrations in present study when compared with the reported one in $[24,25]$. The concentrations of toxic heavy metals $\mathrm{Pb}$ and $\mathrm{Cd}$ were below the method detection limit in the present analysis and as reported before in Ethiopian khat $[6,11]$. But they were reported in Yemeni Khat with the concentration range of $\mathrm{Cd}$ and $\mathrm{Pb}$, of 0.006 to 0.053 $\mu \mathrm{g} / \mathrm{g}$ and 0.066 to $0.7 \mu \mathrm{g} / \mathrm{g}$ respectively and also in Ethiopia and Kenya as reported before [1, 3]. In addition $\mathrm{Cd}$ was detected in some type of Ethiopian khat leaves as reported before [25]. In fact, the concentration of the toxic heavy metals are expected to be very low in Ethiopian khat since these metals are related to environmental pollution caused by different industrial activities.

Table 6. Comparison of Levels of some Elements with the Available Data in Literature (Fresh-Weight Basis).

\begin{tabular}{|c|c|c|c|c|c|c|c|}
\hline \multirow[t]{2}{*}{ Khat origin } & \multicolumn{6}{|c|}{ Element (wet-weightbasis, $\mu \mathrm{g} / \mathrm{g}$ ) } & \multirow[t]{2}{*}{ Reference } \\
\hline & $\mathrm{Fe}$ & Zn & $\mathrm{Cu}$ & $\mathbf{C r}$ & Cd & $\mathbf{P b}$ & \\
\hline Ethiopian & $33.87-59.04$ & $6.80-8.96$ & $3.41-4.19$ & $1.08-1.62$ & ND & ND & Present study \\
\hline Ethiopian & $53.9-82.8$ & $5.18-9.40$ & $1.85-5.53$ & $0.66-3.47$ & ND & ND & 6 \\
\hline Yemeni & Not reported & $3.5-12$ & $2.6-10.5$ & Not reported & $0.006-0.053$ & $0.066-0.7$ & 19 \\
\hline Ethiopian & $273.05-1497.5$ & $9.5-197.5$ & $5.44-9.05$ & Not reported & $0.02-4.55$ & ND & 24 \\
\hline Ethiopian & $573.33-741.67$ & $157-205$ & $16.9-22.5$ & $1.52-4.09$ & ND-2.12 & ND & 25 \\
\hline
\end{tabular}

\subsection{The Level of Trace Metal in Relation to Recommended Daily Allowance}

Since fresh khat is chewed for its stimulating property, the result in terms of dry weight basis is converted to fresh (wet) basis using conversion factor of each khat type (table 5). In most cases, the average quantity of khat chewed by Ethiopians ranges from 100 to $500 \mathrm{~g}$ daily $[1,6]$. In this study the range of metal concentration of the tested heavy metals on fresh weight basis is given in table 5. As shown in the table, chewing khat contributes $0.68-0.896 \mathrm{mg} / 100 \mathrm{~g}$ and 0 . $341-0.419 \mathrm{mg} / 100 \mathrm{~g}$ fresh weight basis per day of $\mathrm{Zn}$ and $\mathrm{Cu}$ respectively. In the same way chewing chat contributes $0.108-0.162 \mathrm{mg} / 100 \mathrm{~g}$ on fresh weight basis per day of Cr. In addition, chewing $100 \mathrm{~g}$ of fresh khat contributes 3.38-5.904 $\mathrm{mg} / 100 \mathrm{~g}$ Fe on fresh weight basis.

As per 1989 recommended daily allowance (RDA) levels for $\mathrm{Cu}$ and $\mathrm{Zn}$ are 2-3 $\mathrm{mg} /$ day and $12-15 \mathrm{mg}$ /day respectively [23].These value do not pose a health risk if up to $100 \mathrm{~g}$ of the stated fresh khat are taken, rather zinc from other sources is required to satisfy the required amount.

However, further increase in khat consumption may satisfy the maximum recommended $\mathrm{RDA}$ value of $\mathrm{Cu}$ and additional intake of $\mathrm{Cu}$ from other source may pose health impact. Based on 1989 recommended daily allowance the levels of $\mathrm{Fe}$ are bellow the RDA recommended limit and require additional source of these metal to satisfy the individual need [23]. In addition, chewing the tested khat varieties contribute insignificant amount of the toxic heavy metals $\mathrm{Cd}$ and $\mathrm{Pb}$.
Generally based on the current status, chewing Ethiopian khat in addition to stimulating property, it contribute appreciable amount of trace metals for the daily requirement of the individuals and are free from toxic heavy metals . Particularly, khat could be good source of $\mathrm{Fe}$ and $\mathrm{Zn}$ for individuals who are chewing this plant.

\subsection{Comparison of Analyzed Heavy Metals in Khat Samples with WHO Recommended Limit for Plant}

The results in this study indicates that the concentration of $\mathrm{Fe}$ ranges between 33.87-59.04 $\mu \mathrm{g} / \mathrm{g}$ but the WHO recommended limit of Iron in plants is $20 \mu \mathrm{g} / \mathrm{g}$. In all khat samples, concentration of Iron was recorded above the permissible limit .The high concentration of iron in this study may be due the high ability of plants to absorb the metals from the soil (high Iron content of soil). The permissible limit of Copper for plants is $10 \mu \mathrm{g} / \mathrm{g}$ recommended by WHO. In all analyzed khat samples, concentration of Copper was recorded below the WHO recommended limit. The permissible limit of Cadmium and Leadin plants, recommended by WHO, is 0.02 $\mu \mathrm{g} / \mathrm{g}$ and $2 \mu \mathrm{g} / \mathrm{g}$ respectively, but in this study the concentration of both Cadmium and Lead was not detected. The level of Chromium in the present study ranges between 1.06-1.62 $\mu \mathrm{g} / \mathrm{g}$ and the permissible limit of Chromium for plants is $1.30 \mu \mathrm{g} / \mathrm{g}$ recommended by WHO. The concentration of Chromium in Konso khat was above the permissible limit .Zinc is one of the important trace elements that play a vital role in the physiological and metabolic process of many organisms and at high level, Zinc is neurotoxin .The WHO's recommended limit 
of Zinc in plant is $50 \mu \mathrm{g} / \mathrm{g}$ and in this experiment its value ranges $6.80-8.96 \mu \mathrm{g} / \mathrm{g}$ which is below the permissible limit. So $\mathrm{Zn}$ does not possess potential harm to the plant users .Generally, based on the WHO recommended limit [26] for plant, $\mathrm{Cu}, \mathrm{Zn}, \mathrm{Cr} \mathrm{Pb}, \mathrm{Cd}$ were not found to cause any risk to the people by consuming the khat plants grown in the area where the khat is planted.

\subsection{Statistical Analysis}

Statistical analysis of data was made to verify whether there was a significant difference in metal contents between the three khat varieties analyzed. For the present study, the significance of variation within sample and between samples has been studied using one way ANOVA coupled with Post hoc Tukey HSD test and calculations were made using SPSS20 software. There were a significant difference $((\mathrm{p} \leq 0.05)$ at $95 \%$ confidence interval for $\mathrm{Cr}, \mathrm{Cu}, \mathrm{Fe}$, and $\mathrm{Zn}$ concentrations in all khat varieties determined. And also there was significant variation observed among all the khat varieties when pair-wise comparison was performed (table 7).

Table 7. Analysis of variance (ANOVA) between and within Samples and pair wise investigation between khat varieties at 95\% Confidence Level.

\begin{tabular}{|c|c|c|c|c|c|c|c|c|}
\hline Metals & Comparison & Sumof squares & df & Mean square & $\mathbf{F}_{\text {calculated }}$ & Sig.(P) & Remark & $\begin{array}{l}\text { Pair-Wise } \\
\text { Investigation }\end{array}$ \\
\hline \multirow{2}{*}{$\mathrm{Fe}$} & Between samples & 41329.56 & 2 & 20664.78 & \multirow{2}{*}{$9.00 \times 10^{3}$} & \multirow{2}{*}{.000} & \multirow{2}{*}{$\begin{array}{l}\text { Significance difference } \\
\text { between sample means }\end{array}$} & \multirow{2}{*}{$\begin{array}{l}\text { Significance difference } \\
\text { between all pairs }\end{array}$} \\
\hline & Within samples & 55.11 & 24 & 2.30 & & & & \\
\hline \multirow{2}{*}{$\mathrm{Zn}$} & Between samples & 323.32 & 2 & 161.66 & \multirow{2}{*}{$3.98 \times 10^{3}$} & \multirow{2}{*}{.000} & \multirow{2}{*}{$\begin{array}{l}\text { Significance difference } \\
\text { between sample means }\end{array}$} & \multirow{2}{*}{$\begin{array}{l}\text { Significance difference } \\
\text { between all pairs }\end{array}$} \\
\hline & Within samples & 0.97 & 24 & 0.04 & & & & \\
\hline \multirow{2}{*}{$\mathrm{Cu}$} & Between samples & 46.22 & 2 & 23.11 & \multirow{2}{*}{$1.58 \times 10^{3}$} & \multirow{2}{*}{.000} & \multirow{2}{*}{$\begin{array}{l}\text { Significance difference } \\
\text { between sample means }\end{array}$} & \multirow{2}{*}{$\begin{array}{l}\text { Significance difference } \\
\text { between all pairs }\end{array}$} \\
\hline & Within samples & 0.35 & 24 & 0.02 & & & & \\
\hline \multirow{2}{*}{$\mathrm{Cr}$} & Between samples & 19.56 & 2 & 9.78 & \multirow{2}{*}{907.83} & \multirow{2}{*}{.000} & Significance difference & \multirow{2}{*}{$\begin{array}{l}\text { Significance difference } \\
\text { between all pairs }\end{array}$} \\
\hline & Within samples & 0.26 & 24 & 0.01 & & & between sample means & \\
\hline
\end{tabular}

\section{Conclusions}

The levels of selected heavy metals in selected Ethiopian khat leaves (C. edulis; Konso, Gidolle and Koyira type khat varieties) were determined by flame atomic absorption spectrometry (FAAS). The optimized wet-digestion method for khat sample analysis was found to be efficient, and it was evaluated through the recovery experiment, anda good percentage recovery was obtained for the heavy metals determined.

The results of the analysis showed that all khat varieties analyzed contains appropriate concentration of essential and trace metals, and they could be source of dietary minerals and trace metals. The level of toxic heavy metals $\mathrm{Cd}$ and $\mathrm{Pb}$ in all khat varieties were too low to be detected by the method used in this study. Indicating that the widely chewable and commercially available Ethiopian khat are free from environmental pollution due to non-essential heavy metals which are usually caused by industrial activities.

The studied metal content of all khat types followed generally similar trends across the varieties that could be arranged in descending order: $\mathrm{Fe}>\mathrm{Zn}>\mathrm{Cu}>\mathrm{Cr}$.

The ANOVA results suggest that there were significant variations in the level of all analyzed elements between the khat varieties which could be attributed to different factors such as age of the harvest khat, geographical and climatical variation, difference in physicochemical nature of the soil, and different agricultural practices among khat cultivators.

\section{Acknowledgments}

We would like to thank the Department of Chemistry, Arba Minch University, Ethiopia, for providing the laboratory facilities and the necessary supports.

\section{References}

[1] Tilahun, E. (2009). Determination of trace metals in commercially available khat (Catha edulis Forsk) in Addis Ababa. M. sc. thesis. Addis Ababa University. 33-42.

[2] Elmi, As. (1983). Khat: Effects of khat on resting and fatigued subjects. Proceedings of an International Conference in Khat. Antananarivo, Madagascar, 153-158.

[3] Ireri, S.M. (2014). Determination of the Levels of Selected Heavy Metals in Soil and in Khat (Catha edulis Forsk) Grown in Kenya. M.Sc thesis. Kenyatta University. 8-20.

[4] Graziani, M., Milella, M. and Nencini, P. (2008). Khat chewing from apharmacological point of view: An update. Substance Use and Misuse, 43:762-783.

[5] Lemessa, D. (2001). Khat (Catha edulis): Botany, distribution, cultivation, usage and economics in Ethiopia. UN-Emergences units for Ethiopia, Addis Ababa. 3.

[6] Atlabachew, M., Chandravanshi, B. S. and Redi, M. (2010).Concentration Levels of Essential and Non-essential Metals in Ethiopian Khat (Catha edulis Forsk). Biol Trace Elem Res, 138:316-325.

[7] Al-Motarreb, A., Baker. K. and Broadley, K. J. (2002). Khat: pharmacological and medical aspects and its social use in Yemen. Phytotherapy Research, 16:403-413.

[8] Saha, S and Dollery, C. (2006). Severe is chaemic cardiomyopathy associated with chat chewing. Journal of the Royal Society of Medicine, 99:316-318.

[9] Milanovic, B. (2008). Qat expenditures in Yemen and Djibouti: An empirical analysis. Journal of African Economies, 17:661.

[10] Belew, M., Kebede, D., Kassaye, M. and Enguoselassie, F. (2000). Themagnitude of khat use and its association with health, nutrition and socioeconomicstatus. Ethiopian Medical Journal, 38:11-26. 
[11] Atlabachew, M., Chandravanshi, B. S. and Redi, M. (2011). Profile of major, minor and toxic metals in soil and khat (Catha edulis Forsk) caltivars inEthiopia. Treads in Applied Science Research, 6:640-655.

[12] Tan, K.H. (1996). Soil Sampling Preparation and Analysis. Marcel Dekker, New York.

[13] Grusak, M.A., Penna, D.D., (1999). The nutrient composition of plants to enhance human nutrition and health. Annu Rev Plant Physiol Plant Mol Biol, 50:133-161.

[14] Nartey, V. K., Haizel, H., Doamekpor, L. K. and Dankyi, E. (2012). Studies on the contribution of fertilizers to heavy metal levels in soils and cocoa from some cocoa farms in the western region of Ghana. Journal of Natural Sciences Research, 2:111-120.

[15] ATSDR (2007). Toxicological profile for lead. U.S. department of health andhuman services, public health service, Atlanta, GA. Case No. 7439-92-1.

[16] Sharma, P. and Dubey, R. S. (2005). Lead toxicity in plants. Brazilian Journal of Plant Physiology, 17:35-52.

[17] Kabata-Pendias, A., (2004). Soil plant transfer of trace elements- an environmental issue. Geoderma, 122:143-149.

[18] Nouri, J.N., Khorasani. B., Lorestani. M., Karami, A.H., Hassani and Yousefi, N. (2009). Accumulation of heavy metals in soil and uptake by plant species with phytoremediation potential. Environ. Earth Sci., 59:315-323.

[19] Matloob, M. H. (2003). Determination of cadmium, lead, copper and zinc in Yemeni khat by anode stripping voltammetry. Eastern Mediterranean Health Journal, 9:28-36.
[20] Raskin, I., Kumar, P.B.A., Dushenkov, S., Salt, D.E. (1994). Bioconcentration of heavy metals by plants. Curr Opin Biotechnol, 5:285-290.

[21] Beyene, D. (1988). Soil fertility research on some Ethiopian Vertisols. In: Jutzi SC, Haque I, McIntire J, Stares JES (eds) Management of Vertisols in sub-Saharan Africa. Proceedings of a Conference Held at ILCA (International Livestock Centre for Africa), Addis Ababa, Ethiopia.223-231.

[22] Itanna, F., Brever, J., Olsson, M. (2008). The fate and bioavailability of trace elements applied to two vegetables farms in Addis Ababa. Afr J Agric Res, 3:797-807.

[23] National Research Council. (1989). Recommended dietary allowance, 10th edn. National Research Council, National Academy Press, Washington, DC.

[24] Ayenew, A., Gebremariam, B., 1 Ephrem, E. (2014).Levels of essential and toxic metals in Ethiopian khat, (catha edulis forsk.). Ethiopian Journal of Environmental Studies \& Management, 7(3): 289-297.

[25] Fenta, A.D., Kidanemariam, A.A. (2015). Profile of Essential and Non-Essential Metals in Soil and in Khat (Catha Edulis Forsk) Leaves Cultivated in Southern Region, Ethiopia. Chem Sci J., 6:3.

[26] Ruqia, N., Muslim, K., Muhammad, M., Hameed, Ur R., Naveed, Ur R., Surrya, S., Nosheen, A., Muhammad, S., Mohib, U., Muhammad, R.,Zeenat, S.,(2015). Accumulation of Heavy Metals (Ni, Cu, Cd, Cr, Pb, Zn, Fe) in the soil, water and plants and analysis of physico-chemical parameters of soil and water Collected from Tanda Dam kohat. J. Pharm. Sci. \& Res. 7(3), 89-97. 